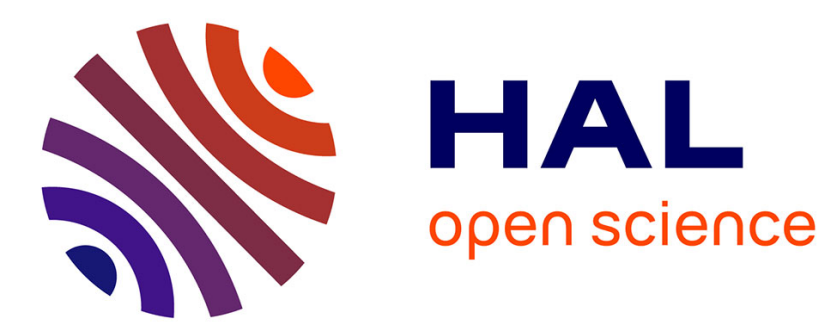

\title{
Business Modelling for Smart Continual Commissioning in ESCO Set-Ups
}

Karsten Menzel, Andriy Hryshchenko

\section{To cite this version:}

Karsten Menzel, Andriy Hryshchenko. Business Modelling for Smart Continual Commissioning in ESCO Set-Ups. 18th Working Conference on Virtual Enterprises (PROVE), Sep 2017, Vicenza, Italy. pp.307-319, 10.1007/978-3-319-65151-4_29 . hal-01674909

\section{HAL Id: hal-01674909 \\ https://hal.inria.fr/hal-01674909}

Submitted on 3 Jan 2018

HAL is a multi-disciplinary open access archive for the deposit and dissemination of scientific research documents, whether they are published or not. The documents may come from teaching and research institutions in France or abroad, or from public or private research centers.
L'archive ouverte pluridisciplinaire HAL, est destinée au dépôt et à la diffusion de documents scientifiques de niveau recherche, publiés ou non, émanant des établissements d'enseignement et de recherche français ou étrangers, des laboratoires publics ou privés. 


\title{
Business Modelling for Smart Continual Commissioning in ESCO Set-Ups
}

\author{
Karsten Menzel and Andriy Hryshchenko \\ University College Cork, School of Engineering, Western Gateway Building, Western Road, \\ Cork T12 XF62 Ireland \\ \{Karsten menzel, k.menzel@ucc.ie\}
}

\begin{abstract}
The availability of sensors, smart meters, and so called 'intelligent devices' (IoT) enables owners and tenants to better understand and flexibly adjust the status of buildings and their systems according to their needs. However, it also requires a more intense and detailed knowledge about how to exploit, analyse and manage 'big data' compiled from these devices. Building operators, facility managers and energy suppliers are expected to collaborate and to share this data aiming to deliver more holistic, comprehensive services to clients (i.e. owners and tenants of buildings). This paper discusses how so called ESCObusiness models (energy service companies) and CC-business models (continuous commissioning) can be integrated through sharing of big data and collaboration of major stakeholders involved in building operation, energy supply and engineering consultancy. It explains how building owners will benefit from the availability of such comprehensive, collaborative services.
\end{abstract}

Keywords: Big Data, Collaboration, Continual Commissioning, Energy Service Company, Facility Management.

\section{Introduction}

ESCOs emerged in the United States in the 1970s, after the oil crisis. The concept then gradually spread to Europe and Japan where the ESCO industry has successfully developed. Today, the ESCO concept has spread with varying success to most industrialised and developing countries worldwide. [1] There are a variety of descriptions of what an ESCO is. The EU Energy Service Directive defines an ESCO as " a natural or legal person that delivers energy services and/or other energy efficiency improvement measures in a user's facility or premises, and accepts some degree of financial risk in doing so. The payment for the services delivered is based (either wholly or in part) on the achievement of energy efficiency improvements and on the meeting of the other agreed upon performance criteria". [2].

The terms ESCO and Energy Performance Contracting (EPC) [3] were not widespread in Ireland, but instead an ESCO-type work is often referred to as Contract Energy Management (CEM). As of 2009, there were only 15 companies identified as energy service providers [4]. More recent reports [5] indicate that the potential market size for ESCOs in Ireland could be as high as $€ 110$ million per year by 2020. 
The ESCO market in Ireland is mainly focussed on co-generation and supply-side projects in the service sector (e.g. hotels and leisure centres). A smaller section of the industry targets district heating and renewable energies. [6] Build Own Operate Transfer (BOOT) arrangements are the most commonly used contract type, these having no performance guarantees. [4]

Continuous Commissioning (CC) is - according to a definition developed by the Energy Systems Laboratory (ESL) - “... an ongoing process to resolve operating problems, improve comfort, and optimize energy use". CC ${ }^{\circledR}$ is trademarked by ESL. $\mathrm{CC}{ }^{\circledR}$ can be broken down in two phases, consisting of a total of seven steps (Table 1).

Table 1. Phases and steps of $\mathrm{CC}^{\circledR}$

\begin{tabular}{|c|c|}
\hline Phase 1 & Phase 2 \\
\hline $\begin{array}{l}\text { Visit the site to identify and quantify } \\
\text { potential measures and savings. }\end{array}$ & $\begin{array}{l}\text { Implement Continuous } \\
\text { Commissioning measures. }\end{array}$ \\
\hline $\begin{array}{l}\text { Develop performance baselines for } \\
\text { energy and comfort. }\end{array}$ & $\begin{array}{l}\text { Identify changes in operating } \\
\text { procedures for the building staff. } \\
\text { Document energy savings and } \\
\text { comfort improvements } \\
\text { in accordance with the International } \\
\text { Performance Measurement and } \\
\text { Verification Protocol (IPMVP). }\end{array}$ \\
\hline $\begin{array}{l}\text { Examine the building in detail to } \\
\text { identify: } \\
\text { * operating and comfort problems, } \\
\text { * component failures or } \\
\text { * degradation, and causes of system } \\
\text { inefficiency. }\end{array}$ & $\begin{array}{l}\text { Track/verify energy and comfort } \\
\text { performance for at least one year in } \\
\text { accordance with the IPMVP. }\end{array}$ \\
\hline
\end{tabular}

Figure 1 overleaf summarises the 'integration challenge'. The traditional business model of FM-operators is presented on the top; i.e. specialist contractors operate single building services systems using their detailed expertise. Secondly, energy providers sell one or multiple forms of energy to owners and FM-providers (central part of figure). Currently, the thermal comfort monitoring is either not or only in a very limited format executed (centre right).

The lower part of Figure 1 represents the extended scope (and thus the extended risk) for ESCO providers or building owners, since energy transformation (e.g from renewable co-generators) and energy distribution (e.g. across groups of buildings and CHP, storages, etc.) are pre-requisites for holistic energy provision and management.

The right part of figure 1 depicts the different 'real time' data sources and the stakeholders. 'Real-time' data sources can be better described as "time-series data" and may include: (i) information about the status of systems and components (log-files, e.g. valve on/off etc.), (ii) meter data (e.g. from smart meters), (iii) sensor data (e.g. room temperature), (iv) process documentation (e.g. from maintenance tickets).

These 'time-series data streams' are also called dynamic data or fact data. This data delivers "big data" to the FM and constructions sectors in the range of hundreds of million data sets per building. [7] 


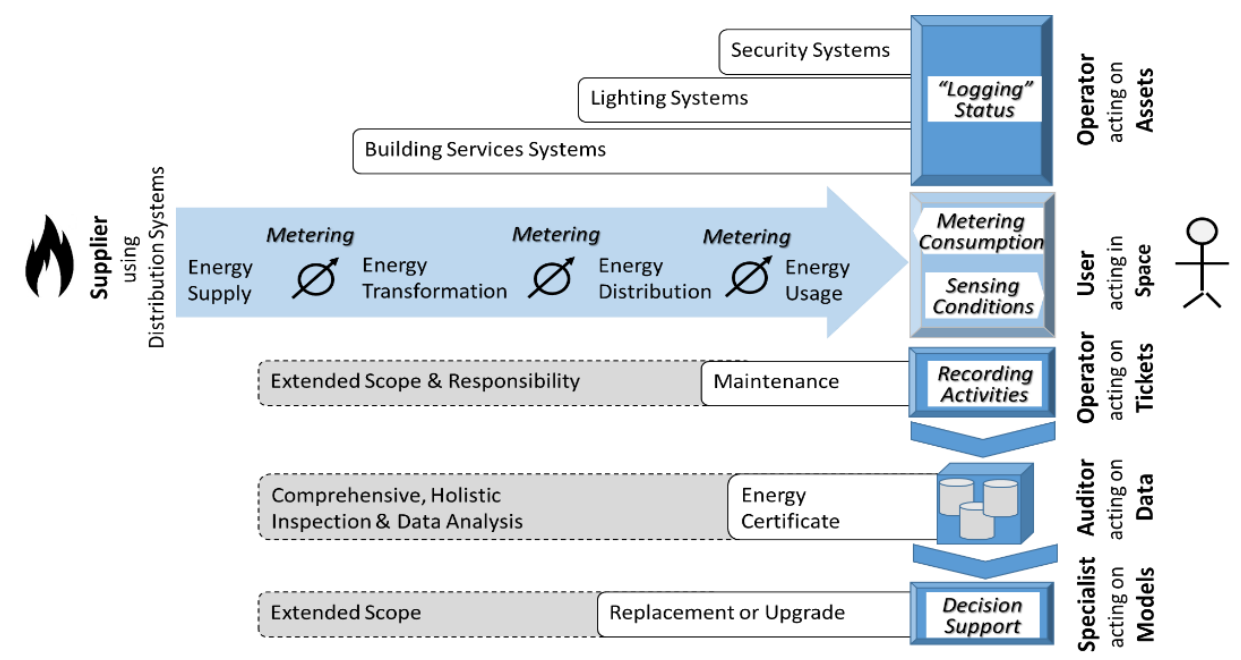

Fig. 1. The ESCO \& $C C \circledR$ integration challenge

For data analysis purposes dynamic data can be combined with so called 'static data' (also called dimensional data) which can be compiled from (i) EMS (energy management systems), (ii) BAC (building automation and control systems), (iii) Documentations or computer models (e.g. BIM), and (iv) MMS (maintenance management systems) (see figure 2).

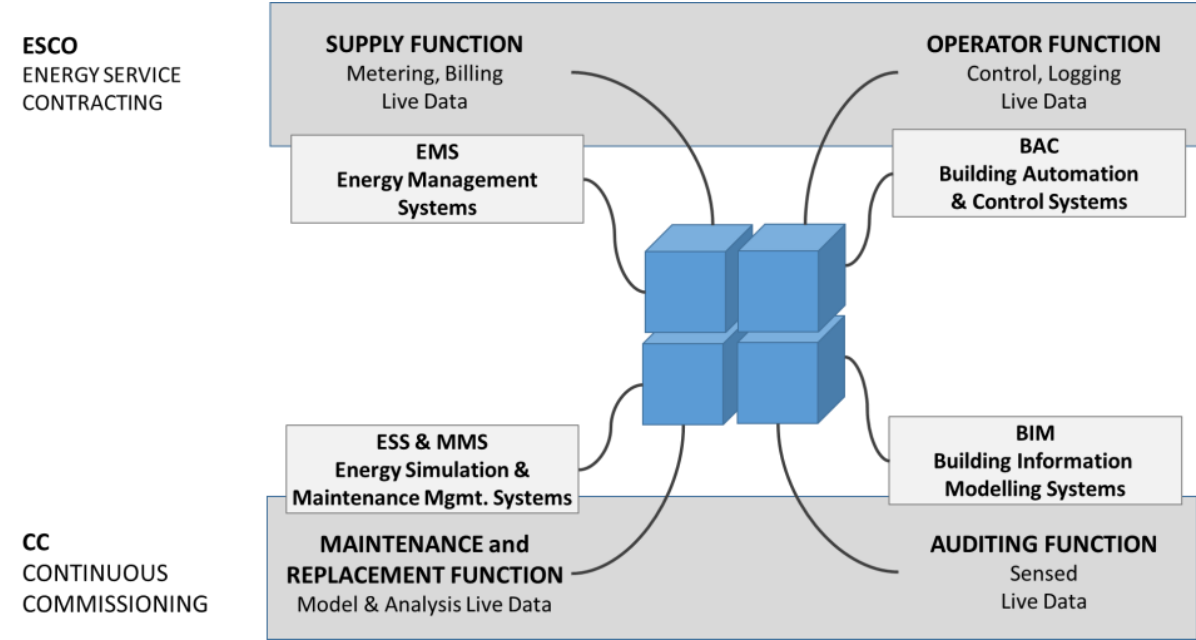

Fig. 2. Integration of dynamic, big data with static data

The extension of ESCO-models with up-to-date CC ${ }^{\circledR}$ business models can be achieved only through the active collaboration of all involved stakeholders. An overview of these stakeholders was presented in Figure 1 (right). Collaboration can be heavily supported through the usage of integrated, shared reporting and analysis tools (see figure 2 centre). 


\section{Benchmarking and Standards}

Benchmarks are used to identify if a buildings' energy performance is poor, average or good with respect to other buildings of its type. An accurate energy model of the building and its integrated systems is required to assess the building energy use potential, while a monitoring programme is required for the systematic collection of plant or building operating data and energy consumption through the Continual Commissioning (CC) processes.

There are several building performance assessment methods which have been deployed to assess building environmental performance. Table 2 presents a comparison of selected international energy benchmarks in relation to their applicability in Ireland.

Table 2. International Benchmarks Comparison.

\begin{tabular}{|c|c|c|}
\hline Benchmarks & Pros & Cons \\
\hline UK Benchmarks & $\begin{array}{l}\text { - Detailed Information } \\
\text { - Wide Building Range } \\
\text { - Applicable to Ireland } \\
\end{array}$ & $\begin{array}{l}\text { - Not normalized } \\
\text { for Ireland }\end{array}$ \\
\hline USA Energy Star & $\begin{array}{l}\text { - Highly Detailed } \\
\text { - Surveyed Every } 4 \text { Years } \\
\text { - Good Statistical Accuracy } \\
\text { - Wide Building Range } \\
\end{array}$ & \multirow{2}{*}{$\begin{array}{l}\text { - Not easy to } \\
\text { normalize for } \\
\text { Ireland }\end{array}$} \\
\hline $\begin{array}{l}\text { European } \\
\text { Benchmarks }\end{array}$ & $\begin{array}{l}\text { - Detailed } \\
\text { - Wide Building Range } \\
\text { - Online Continuous Monitoring } \\
\text { - Public Access } \\
\text { - Ranking System } \\
\end{array}$ & \\
\hline $\begin{array}{l}\text { Display Energy } \\
\text { Certificates (DEC) }\end{array}$ & $\begin{array}{l}\text { - Normalized for Ireland by SEAI } \\
\text { - Wide Building Range } \\
\text { - Applicable to Ireland }\end{array}$ & $\begin{array}{l}\text { Information not as } \\
\text { detailed } \\
\text { - Buildings are } \\
\text { grouped into } \\
\text { categories } \\
\end{array}$ \\
\hline
\end{tabular}

The most popular benchmarking is the DEC (see Table 2) using a conventional Energy Performance Indicator (EPI) expressing the energy usage per usable floor area [unit $\mathrm{kWh} / \mathrm{m}^{2}$ ]. [8] This is a robust and simple instrument for peer group benchmark. However, there are many variables which can skew the comparison, e.g. Climate (Degree Day Variation), Occupancy, Sample Size, Jurisdiction, Building Standards, Hours of Operation etc.

These issues must be factored into any comparison. Allowances can be made for those variables through different normalisation processes.

Furthermore, more comprehensive methods for performance benchmarking are required, which support the holistic evaluation of (i) energy use, (ii) user comfort, (iii) the integrated operation of building services systems, and (iv) the efficient usage of building spaces. An example for such a methodology has been developed in the EUFP7 project CAMPUS 21 by researchers from industry and numerous academic partners. [9] 


\section{Business Models}

A Business Model (BM) describes the rationale of how an organization creates, delivers and captures value. [10] Business models have changed and adapted over time to suit market conditions. There have been various creators of business model frameworks, but one particularly stands out. Developed by A. Osterwalder, Yves Pigneur, Alan Smith, and 470 practitioners from 45 countries, this is one of the most used BMframeworks. [11], [12].

Osterwalder at al. [10] believes that a BM can best be described through nine basic building blocks showing the logic of how a company intends to make money. These nine blocks cover the four main areas of a business, such as: customer interface, product, infrastructure, and financial aspects. Each of these building blocks are related to other building blocks. The interdependency of these blocks is key to the success of the model. Figure 3 shows how the blocks are linked to each other.

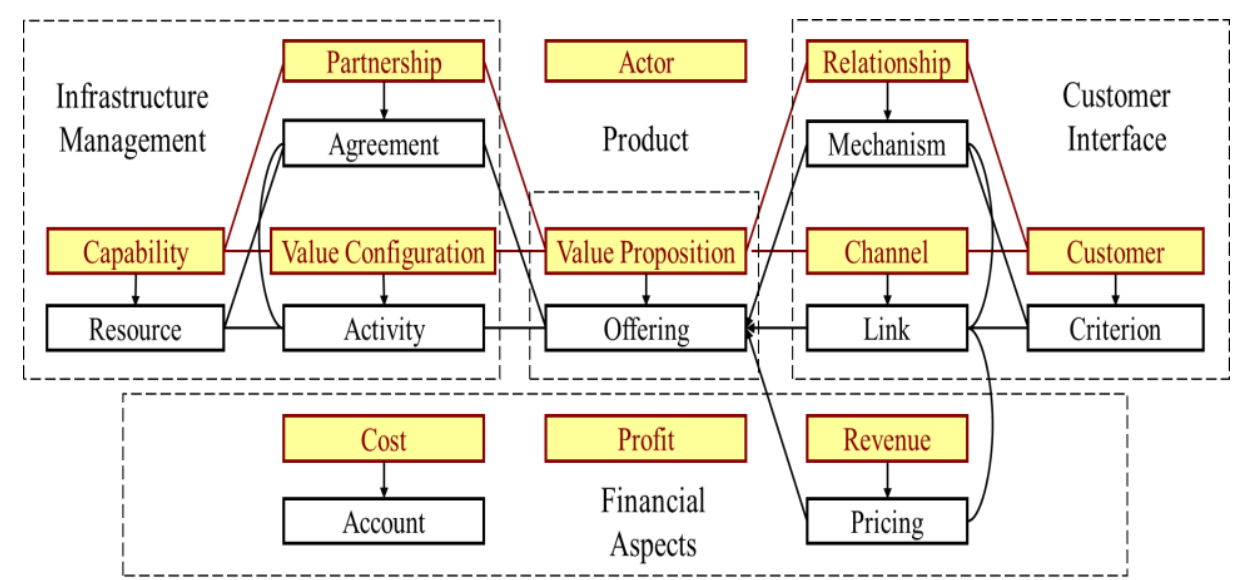

Fig. 3. Interdependency of 9 BM blocks (as per [10])

This business model canvas can be taken as a strategic management template for developing new or documenting existing business models for those providers offering Continual Commissioning services. It will also work as a visual representation describing ESCO's value proposition, infrastructure, customers, and finances for the selected case study to be discussed in subsequent sections.

\section{BM Solutions for Integrated ESCO \& CC®-Services Models}

To profit from innovation, those companies offering $\mathrm{CC}$ service within an ESCO framework need to count not only on product innovation but also on business model design, understanding business design options as well as customer needs and technological trajectories. [13] In this chapter business models for ESCOs providing Continual Commissioning services will be examined against the above Key Elements. 


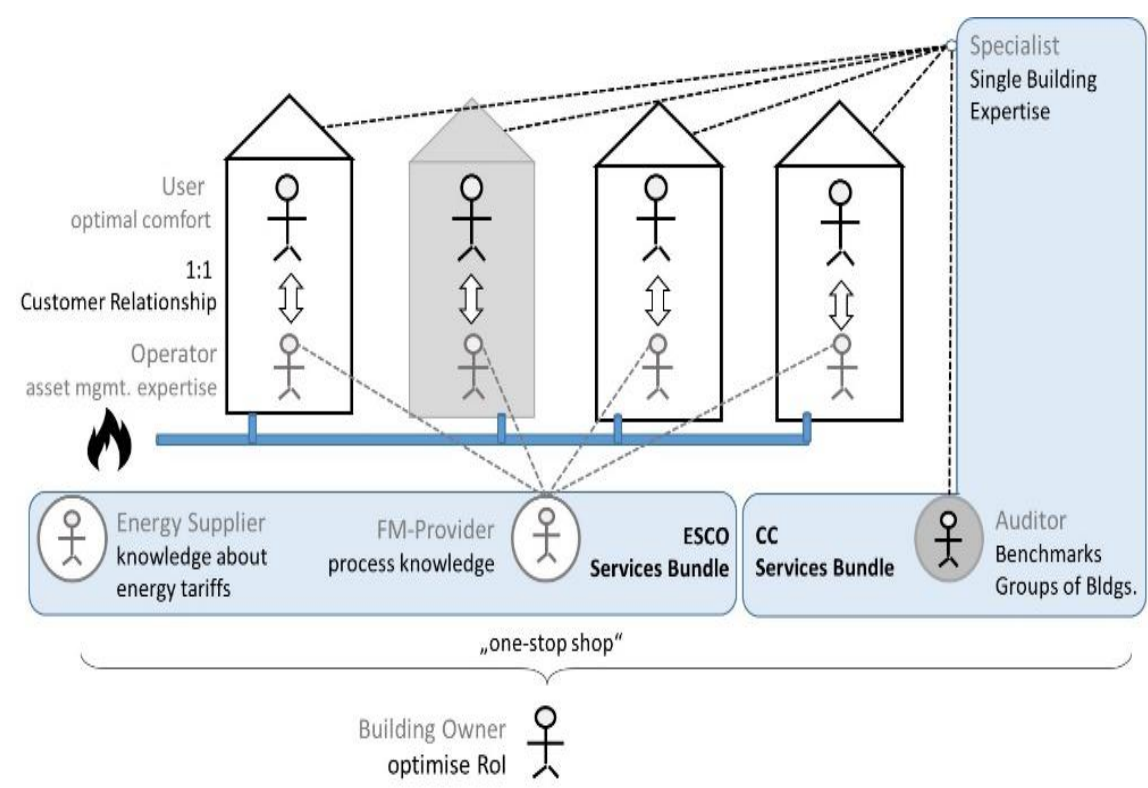

Fig. 4. An integrated BM for holistic ESCO \& CC-services as "one-stop-shop"

Figure 4 clearly illustrates that integrated ESCO \& CC-BM still benefit from the strong 1:1 customer relationship of FM-providers with users on a "location" (building) basis. However, it benefits from the availability of an additional "auditing and benchmarking" function (lower right). Big data and holistic data analysis are the "enablers" for this advanced services offer. The integration of big data (dynamic data) with the building expertise from specialist services (top right) allows the exploitation of the benefits from semantically enriched data, i.e. BIM models.

In summary, CC-business services provide a substantial 'evaluation and risk management' element which complements existing ESCO business models. The implementation of such an 'ESCO \& CC' business model is based on the intensive collaboration of four well known stakeholders, such as: energy suppliers, FMproviders, energy auditors, and engineering specialists. Building owners clearly benefit from such a collaborative approach, since they are provided with access to 'integrated services' through a single interface.

\subsection{Analysis of BMs Available for an ESCO Offering CC® Service}

The purpose of this section is to examine several BM suitable for ESCO offering CC ( service, based on Osterwalder's BM-canvas. Each model will have its advantages and disadvantages for both the client and the ESCO. The information on Key Partners, Key Activities, Key Resources, Customer Relationship, and Channels \& Customer Segments generally remain the same, no matter what type of financing arrangement is decided upon. Thus, for the potential BM the authors will concentrate on Value Proposition, Cost Structure \& Revenue Streams factors as shown in Table 3 overleaf. 
Table 3. Comparison of BM - contracting types for ESCO offering CC.

\begin{tabular}{|c|c|c|c|c|}
\hline $\begin{array}{l}\text { Type of } \\
\text { Financing }\end{array}$ & EPC & Value Proposition & Cost Structure & Revenue Streams \\
\hline $\begin{array}{l}\text { Integrated } \\
\text { Energy } \\
\text { Contract }\end{array}$ & $\mathrm{n} / \mathrm{a}$ & $\begin{array}{l}\text { Supply of Heat and } \\
\text { Power managed by } \\
\text { ESCO plus Energy } \\
\text { Efficiency Upgrades } \\
\text { using an EPC. }\end{array}$ & $\begin{array}{l}\text { Cost structure varies } \\
\text { and depends on } \\
\text { individual contracts. }\end{array}$ & $\begin{array}{l}\text { ESCO sells heat and } \\
\text { power to Customer. } \\
\text { This is combined } \\
\text { with one of the EPC } \\
\text { models below. }\end{array}$ \\
\hline Shared Savings & Yes & & $\begin{array}{l}\text { Cost and savings are } \\
\text { split for a pre- } \\
\text { determined length of } \\
\text { time in accordance } \\
\text { with a pre-arranged } \\
\text { percentage. }\end{array}$ & $\begin{array}{l}\text { ESCO \& Customer } \\
\text { incentivised to } \\
\text { outperform targets as } \\
\text { energy savings are } \\
\text { shared. } \\
\text { Revenue recovered } \\
\text { through reduced } \\
\text { energy consumption, } \\
\text { operation and } \\
\text { maintenance costs. }\end{array}$ \\
\hline $\begin{array}{l}\text { Guaranteed } \\
\text { Savings }\end{array}$ & Yes & $\begin{array}{l}\text { Reduction in } \mathrm{CO}_{2} \\
\text { emissions and } \\
\text { associated energy } \\
\text { costs. } \\
\text { Reduction in } \\
\text { maintenance \& } \\
\text { operation costs. }\end{array}$ & $\begin{array}{l}\text { Customer: } \\
\text { No upfront cost, } \\
\text { invites capital, } \\
\text { ESCO: } \\
\text { guarantees a certain } \\
\text { level of energy } \\
\text { savings, } \\
\text { Advantage: interest } \\
\text { rates of loan usually } \\
\text { much lower. }\end{array}$ & $\begin{array}{l}\text { Only the Customer is } \\
\text { incentivised to reach } \\
\text { energy targets. } \\
\text { Revenue recovered } \\
\text { through reduced } \\
\text { energy consumption, } \\
\text { operation and } \\
\text { maintenance costs. }\end{array}$ \\
\hline $\begin{array}{l}\text { Chauffage } \\
\text { Model }\end{array}$ & Yes & & $\begin{array}{l}\text { Supply by demand } \\
\text { long-time (20-30 } \\
\text { years) contract. } \\
\text { Less complex with } \\
\text { lower transaction } \\
\text { costs and without } \\
\text { need of costly } \\
\text { measurements and } \\
\text { verifications. }\end{array}$ & $\begin{array}{l}\text { Heated / Conditioned } \\
\text { space at a specified } \\
\text { price per energy unit. }\end{array}$ \\
\hline $\begin{array}{l}\text { BOOT (Build- } \\
\text { Own-Operate- } \\
\text { Transfer) }\end{array}$ & No & $\begin{array}{l}\text { Reduction in } \mathrm{CO}_{2} \\
\text { emissions to be } \\
\text { agreed between } \\
\text { ESCO and Customer. } \\
\text { Complete outsourced } \\
\text { model. }\end{array}$ & $\begin{array}{l}\text { Usually no upfront } \\
\text { cost for Customer. } \\
\text { ESCO invites capital. }\end{array}$ & $\begin{array}{l}\text { The ESCO operates } \\
\text { under an agreement } \\
\text { with the Customer } \\
\text { and receives BOOT } \\
\text { payments dependant } \\
\text { on the ESCO's } \\
\text { performance. }\end{array}$ \\
\hline $\begin{array}{l}\text { Energy } \\
\text { Performance } \\
\text { Related } \\
\text { Payments } \\
\text { (EPRP) } \\
\end{array}$ & Yes & $\begin{array}{l}\text { Reduction in } \mathrm{CO}_{2} \\
\text { emissions and } \\
\text { associated energy } \\
\text { costs. }\end{array}$ & $\begin{array}{l}\text { Low capital costs. } \\
\text { Improvements done } \\
\text { by ESCO paid by the } \\
\text { Customer. }\end{array}$ & $\begin{array}{l}\text { ESCO is incentivized } \\
\text { to improve energy } \\
\text { efficiency with } \\
\text { performance-related } \\
\text { payments. }\end{array}$ \\
\hline
\end{tabular}




\section{Case Study}

The purpose of this section is to present an initial case study based on the building of the Environmental Research Institute (ERI) located on the campus of University College Cork, Ireland. The case study illustrates how energy monitoring analysis (as it would be executed by an ESCO) could be extended with additional CC ${ }^{\circledR}$-services enabled by holistic sensor data analysis. It explains how $\mathrm{CC} 囚$-services can be used in a collaborative way, to identify potential sources for slow system's degradation.

\subsection{Energy Use}

The usage of supplies (i.e. electricity, natural gas and mains water) for the ERI building is monitored daily and available to authorised stakeholders through a web interface. For the initial pre-commissioning analysis, it was decided to analyse the information available for the last five years, i.e. from 2012 to 2016. All necessary data is obtained and compiled with additional calculations, so the trend of the building's energy performance became clearly visible. The following Figure 5 aggregates these data.

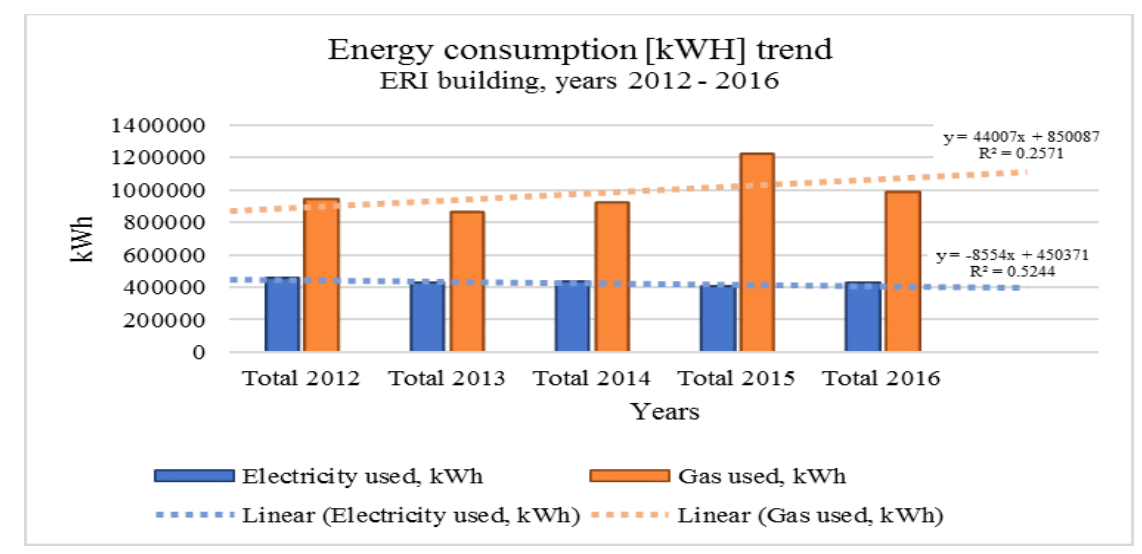

Fig. 5. The ERI energy consumption trend for the last five years.

At this point it is possible to suggest while electricity use in the building remains stable, the natural gas consumption (which is mostly used for heating and for preparation of the domestic hot water) constantly increases. This indicates that there might be an urgent need to arrange for the execution of continuous commissioning services aiming to identify the reason(s) of such an increase. Furthermore, these commissioning procedures, if repeated continually, would prevent such an increase in the future.

The following Figure 6 is representing the financial aspect of the building's ownership, i.e. the combined costs of consumed energy-resources and water in the building for the same last five years' period.

The energy performance analysis also confirms the increasing expenditure for the building's use during the period from 2013 to 2015. One can also observe that in the last year (2016) the cost for gas supply decreases. This is due to a milder winter and not 
due to improved building operation. The main factor in this case is incensement of natural gas' use for heating. Thus, the HVAC-system should be definitely included in $\mathrm{CC} \AA$-procedures. The above results can be used as a 'client-motivation factor' during $\mathrm{CC} \circledast$ contract negotiations.

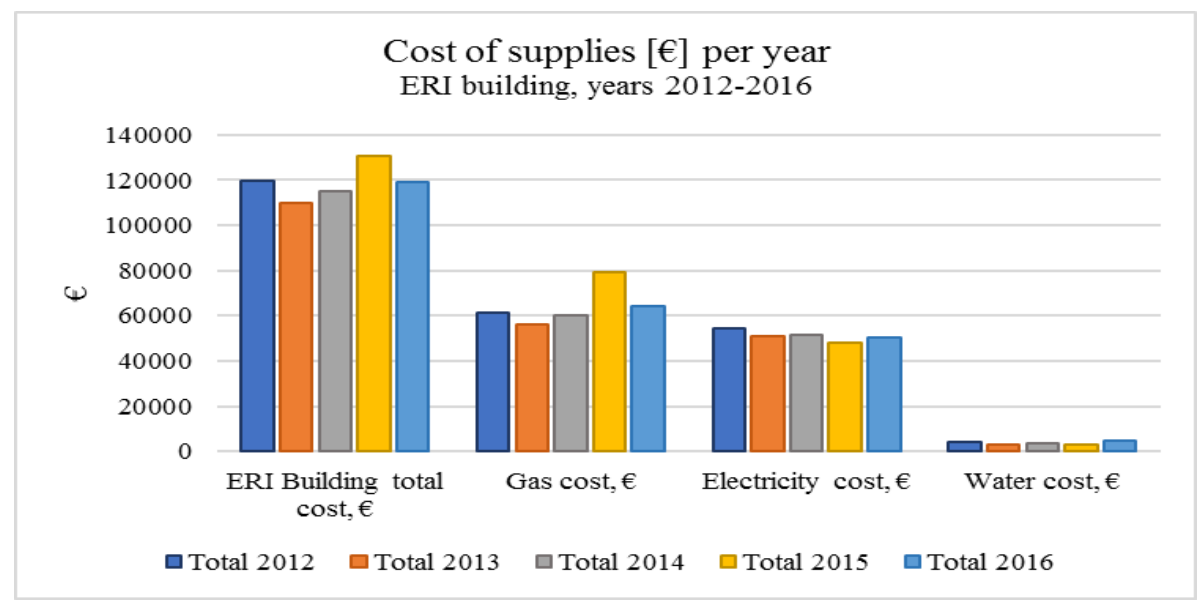

Fig. 6. Cost of supplies for the building, 2012 - 2016.

\subsection{Added Value through Joint Usage of Thermal Comfort Analysis Data}

Based on the above energy metering analysis it is very hard for a building operator to develop an understanding why an increased energy use is documented. The usual approach would be to work on a boiler inspection and maintenance.

However, with increasing "building intelligence" malfunctioning monitoring and control components can also contribute to a degradation of building services systems. In case of our example building, the heating system starts to operate in the event that in three rooms the temperature falls below a set threshold (e.g. $18^{\circ} \mathrm{C}$ ). Thus, the commissioning of (temperature) sensors becomes equally important to e.g. the CC $®$ of boilers and pumps.

One should notice that the example building is equipped with approximately 300 data points. Assuming 15 minute reading intervals ca. 30000 values need to be analysed by the local facility manager daily. One should further notice that the selected building has a total floor area of approx. $2.500 \mathrm{~m}^{2}$ distributed across three floors (only), i.e. the building is a relatively small commercial building.

It becomes easily clear that modern, innovative data analysis techniques are required. In our show case an Oracle Data Warehouse Platform is used to integrate dynamic data from different systems with dimensional data from BAC and BIM. The data integration through a staging area ensures that dimensional data provided by different partners can be verified and cleansed before it is shared. Similar verification and cleansing methods are in place for the dimensional data. [7] 
Figure 7 presents two screen shots from the DW-platform. In the left part a very low average annual temperature $(-11.64 \mathrm{oC})$ is displayed for one sensor. This "aggregated value" is the starting point for the Facility Manager to identify the root-cause for a negative room temperature. In the right part of the picture the result of $C C \AA$ is displayed, namely that commencing on 21 st-June the average daily temperature "jumps" from minus $1000 \mathrm{oC}$ to a reasonable value of $23.84 \mathrm{oC}$.

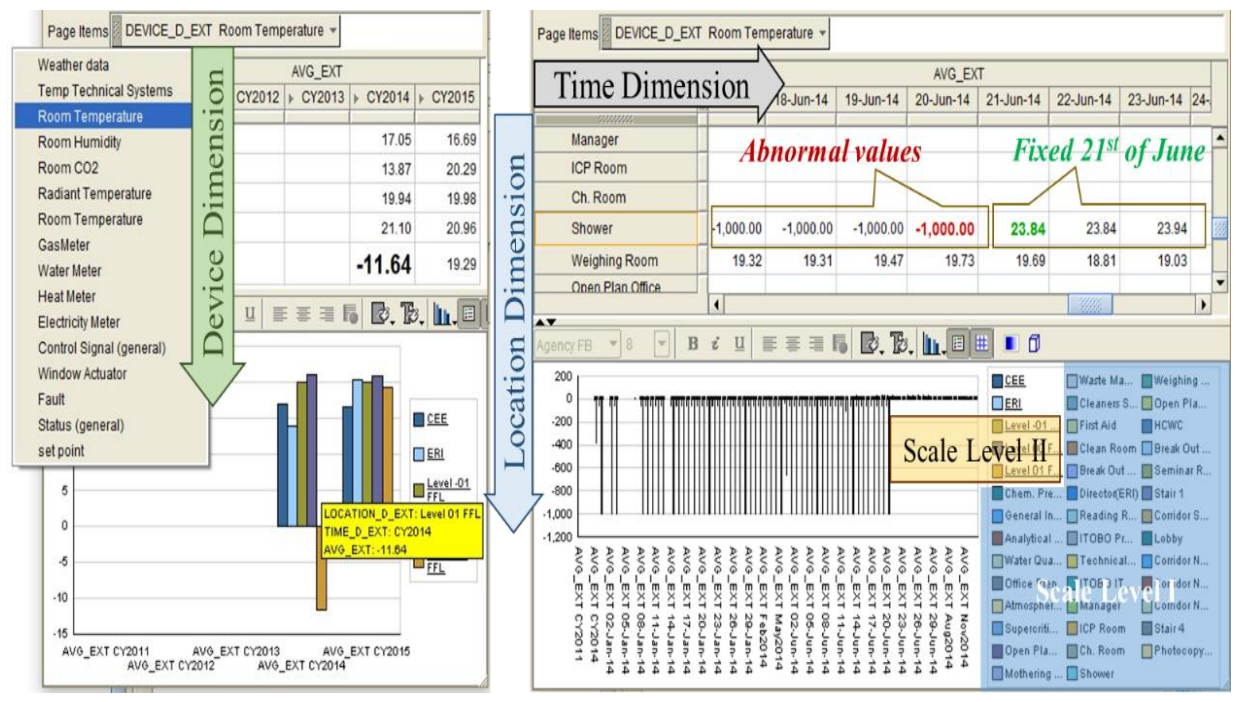

Fig. 7. Identification of malfunctioning sensor through comfort analysis.

Additionally, the interface presented in Figure 7 visualises the different dimensions used to analyse the dynamic, fact data. In the left part of the pictures we visualise the "Device Dimension", i.e. a list and grouping of all monitoring devices (including meters, sensors, and control feedback signals (e.g. on/off)). In the right part we visualise the location dimension (including spaces, storeys, buildings, and sites). Both views also include a time dimension, with three hierarchy levels, such as year, month, and day.

The above visualisation demonstrates that different stakeholders joint forces, since the data analysis platform benefits from (i) the topological and electrical engineering knowledge defining how automation components are interconnected (device dimension), (ii) the topological and architectural knowledge defining what spaces exist, of what type these spaces are and how these spaces are grouped e.g. on storeys (location dimension), and (iii) the mechanical engineering knowledge defining what components are installed in what rooms and what additional sensors and meters exist to monitor building services systems (e.g. supply and return temperature).

\section{Summary and Conclusions}

In general, the market for Energy Services Companies (ESCO) in Ireland has been underdeveloped. A holistic view towards Continual Commissioning as part of ESCO- 
BM should be developed with involvement of all relevant stakeholders working collaboratively together. A radical paradigm shift is required to achieve this goal.

Business model innovation allows for the creation of new services when fully exploiting the potential of advanced infrastructure features (e.g. the availability and accessibility of big data). Additionally, companies must understand their competitive advantages. For example FM-providers will benefit from their 'in-depth' 1:1 customer relationship and their detailed understanding of various building services and automation systems and thus can deliver 'local services' in an efficient way. In comparison stakeholders must also be capable to identify challenges and disadvantages. In our case study none of the so called 'traditional' stakeholders had access to all available monitoring data. This 'limited' access to dynamic (big) data and the absence of static or 'dimensional' data restricts the capabilities of all stakeholders to execute deep data analysis. The collaboration of all stakeholders being involved in ESCO and CC® service provision is an essential pre-requisite for the establishment of holistic data analysis and the provision of performance audits.

\subsection{Some Thoughts about the Ownership of Big Data Compiled from Buildings}

An unsolved problem in the above use case is the ownership of data. Furthermore, it also needs a discussion in the Facilities Management community what authorities and responsibilities are linked to the 'ownership' of data, i.e. the responsibility for the compilation, storage, and long-term maintenance of accurate, complete and consistent data sets.

The "lessons learned" from industry-driven research projects [14], [15] in which the authors were recently involved shows, that required 'up-front' investments in data consistency pay back in later project phases through much lower efforts for data cleansing and data quality management. Thus, providers of $\mathrm{CC} \otimes$, ESCO, and FMservices shall aim to convince their clients to enter 'mid-term' or 'long-term' contractual agreements. Those contractual agreements exist, e.g. in the form of publicprivate-partnerships.

The government, as the creators of policy and legalisation, need to drive the ESCO agenda. Policy needs to reward businesses for tackling $\mathrm{CO}_{2}$ emissions. They also need to create an environment whereby the buildings' owners and managers be more comfortable when dealing with ESCOs. In Ireland the National Energy Services Framework [16] will convey regulation to the ESCO market to bring clarity to both the ESCO industry and potential clients. The BM extension approach proposed in this paper could also support the development of an Irish Continual Commissioning market, especially by those stakeholders currently utilising "reactive maintenance" BM.

Acknowledgements: Parts of this work were supported by the European Commission, projects CAMPUS 21 and BaaS. 


\section{References}

[1] W.-S. Fang and S. M. Miller, "The Effect of ESCOs on Carbon Dioxide Emissions," Applied Economics, vol. June 2013, no. n.a., p. 30, June 2013.

[2] EU Parliament, "Energy end-use efficiency and energy services (Directive 2006/32/EC)," European Parliament, Brussels, 2006.

[3] SEAI, "Energy Performance Contracting Handbook," 25 October 2012. [Online]. Available: http://www.seai.ie/Your_Business/Energy-Contracting/Support-andGuidance/.

[4] IFC, "Energy Service Company Market Analysis," International Finance Corporation, Washington, DC 20433 USA, 2011.

[5] Codema, "Codema Publications," Codema, 16 October 2015. [Online]. Available: http://www.codema.ie/publications. [Accessed 1 November 2016].

[6] SERVE Consortium, "Deliverable D6.10," EC, Brussels, 2012.

[7] K. Menzel, A. Hryshchenko and K. Mo, "Why and how to assess the quality of building performance data," in eWork ad eBusiness in AEC - Proceedings ECPPM, Vienna, 2014.

[8] CIBSE, "Guide F - Energy Efficiency in Buildings," Chartered Institution of Building Services Engineers, London, 2008.

[9] D. Browne, K. Menzel and S. Deng, "Performance Indicators to evaluate buildings' systems' performance," in eWork and eBusiness in AEC - Proceedings of ECPPM, London, 2014.

[10] A. Osterwalder and Y. Pigneur, Business Model Generation, Self Publ., 2009.

[11] OMICS, "Business model," 2014. [Online]. Available: http://research.omicsgroup.org/index.php/Business_model.

[12] T. Burkhart and et.al., "ANALYZING THE BUSINESS MODEL CONCEPT - A COMPREHENSIVE CLASSIFICATION OF LITERATURE," ICIS 2011, Saarbrücken, Germany, 2011.

[13] D. Teece, Business Models, Business Strategy and Innovation, 2009.

[14] K. Katsigarakis, K. D. Kontes, J. Rojicek, C. Valmaseda, J. Hernandez and D. Rovas, "An ICT platform for building analytics," in eWork and eBusiness in AEC - Proceddings of ECPPM, London, 2014.

[15] A. Mahdavi, M. Schuss, K. Menzel and D. Browne, "Realization of ICT potential in improving the energy efficiency of buildings. CAMPUS $21, "$ in eWork and eBusiness in AEC - Proceddings ECPPM, London, 2011.

[16] SEAI, "National Energy Services Framework Overview," Sustainable Energy Authority of Ireland, Dublin, 2013. 